\title{
Budakova Anera kao moliteljica i junakinja
}

\author{
DeAN SLAVIĆ* \\ • https://doi.org/10.31823/d.28.3.4 • \\ UDK: 82-311.2 Budak, M. • Izvorni znanstveni rad \\ Primljeno: 2. prosinca 2019. • Prihvaćeno: 8. rujna 2020.
}

* Prof. dr. sc. Dean Slavić,

Filozofski fakultet

Sveučilišta u Zagrebu, Ivana Lučića 3, 10000 Zagreb, Hrvatska, dean.slavic@gmail.com

Sažetak: Roman je naglašeno hibridni žanr koji može sadržavati i elemente tragedije. Molitelj/suppliant/ u tragedijama i tragičnim naracijama redovito ispunjava četiri uvjeta: a) žensko je biće ili je osoba podređena u društvu; b) prijeti joj nasilje $i$ često smrt; c) ne može govoriti ili ne može prenositi obavijesti; d) nije ni protagonist ni antagonist. Anera iz romana Ognjište književnika Mile Budaka zadovoljava nabrojene uvjete, s time što dijelom odstupa u posljednjem. Ona dobiva veliku količi$n u$ prostora u romanu $i$ inteligencijom je bliska protagonistu Lukanu. Anera također dobrim dijelom ispunjava uvjete koje Lynette Porter postavlja pred junaka, no nedostaje joj element pobjede nad zlom koju ostvaruje protagonist Lukan. S Anerina bi stajališta Ognjište bilo tragedija osvete - ali njezine karakteristike ne određuju roman u žanrovskoj cjelini.

Ključne riječi: Mile Budak, Ognjište, Anera, tragedija, roman, molitelj, glavni junak.

\section{Uvod: pregled članka i hipoteza; osnove književnikova životopisa ${ }^{1}$}

Članak dokazuje da Anera iz Budakova romana Ognjište ima obilježja vrste lika koji se naziva molitelj /eng. suppliant/. Anera biva bliska junakinjama, ali nije vodeći lik - nije protagonist. Nakon uvoda, prvi dio članka dokazuje opravdanost uporabe termina iz teorije tragedije u tuma-

${ }^{1}$ Iako nije povezan s temom članka, umjetnikov je životopis ovdje pružen zbog slabije dostupnosti nekih bitnih podataka iz Budakova života. 
čenju romana. U drugom se dijelu prikazuju osobine molitelja te se određuje šira obitelj likova koja nosi ime pharmakos i kojoj molitelj kao vrsta pripada. Idući dio nalazi obilježja molitelja u Anerinim postupcima, riječima i djelima. Četvrti dio prikazuje sličnosti ovoga lika protagonistu jer zauzima mnogo prostora u romanu, ali se ističu i razlike zbog činjenice da ne zadaje konačan udarac antagonistu.

Mile Budak (1889. - 1945.) bio je hrvatski književnik, odvjetnik i političar te istaknuti pripadnik ustaškoga pokreta. Godine 1932. preživio je atentat koji je organizirala tajna policije Kraljevine Jugoslavije. U doba NDH bio je ministar bogoštovlja i nastave, poslanik u Berlinu i ministar vanjskih poslova. Potpisao je jedan od rasnih zakona, onaj koji Židovima zabranjuje djelovati u kulturi, što valja osuditi. Činjenica da je Kraljevina Jugoslavija bila proglasila rasne zakone 1940. godine slabije je poznata, ali ne opravdava one koji su slične zakone proglasili nakon toga. Pohvalne su Budakove aktivnosti koje je poduzimao za spas Židova kojima je prijetila deportacija u koncentracijske logore, o čemu svjedoče pisma koja su objavili Tomislav Jonjić i Stjepan Matković. ${ }^{2}$ Krleža je također vjerovao da mu je upravo Budak pomogao u doba progona. ${ }^{3} \mathrm{Na}$ početku rata održao je, nažalost, nekoliko govora u kojima je vjerojatno bilo i rečenica koje se mogu shvatiti kao poziv na nasilje. U tim su se nastupima jamačno čuli i pomirljivi tonovi, jer beogradsko Novo vreme 19. kolovoza 1941. na trećoj stranici u povodu govora u Virovitici izvješćuje o glasu razbora iz Hrvatske. ${ }^{4}$ Ocjene njemačke tajne službe, osobito Hansa Helma, optužuju Budaka za otvorenost prema Židovima te za suradnju s dr. Zimmermanom i crkvenim krugom koji su osuđivali nacionalsocijalističku politiku. ${ }^{5} \mathrm{U}$ doba sloma fašističke Italije kao ministar vanjskih poslova gorljivo je tražio priključenje dalmatinskih, kvarnerskih i istarskih područja NDH, što vlasti Trećega Rajha nisu dopustile, a Budak je zbog nediplomatskih postupaka izgubio ministarsko mjesto. Nakon sloma NDH predao se u Austriji s kćeri Grozdanom engleskim snagama koje su ga izručile komunističkoj vojsci nove Jugoslavije. Optužen je u Zagrebu, među ostalim, za veleizdaju (optužnica K. 68/1945), a Vojni sud II. armije osudio ga je na smrt vješanjem; kazna je vjerojatno izvršena 7. VI. 1945. Budakova kći Grozdana Budak, koja se nije bavila politikom, ubijena je kraj Škofje Loke 25. V. 1945. u 21. godini. Budakovu je političku djelatnost dobro prosudio Branimir Jelić, istaknuti borac za hrvatsku državnost koji nije bio umiješan u nasilja i zločine

\footnotetext{
${ }^{2}$ Usp. T. JONJIĆ, S. MATKOVIĆ, Iz korespondencije dr. Mile Budaka (1907. - 1944.), Zagreb, 2012., 442., 445., 607-608.

${ }^{3}$ Usp. isto, 170. Ako je Budak spasio život Krleži, onda ga je spasio i njegovoj supruzi Leposavi Kangrga.

${ }^{4}$ Usp. D. JELČIĆ, Pred novu plovidbu, u: M. BUDAK, Musinka, Zagreb, 1990., 322.

${ }^{5}$ Usp. I. PETRINOVIĆ, Mile Budak - portret jednog političara, poglavlje Primedbe o političkoj delatnosti ministra prosvete, Split, 2002., bez oznake stranice.
} 
počinjene tijekom II. svjetskoga rata i izravno nakon njega: bilo bi bolje za Milu Budaka, za njegovu obitelj i za naš hrvatski narod da se nikada nije bavio politikom.

\section{Roman s tragičnim elementima}

Lodge piše da je umjetnička proza proždrljiva $i \gg s$ sposobna prisvojiti sve vrste stvarnosnih iskaza « pa navodi pisma, novinske članke i druge tekstove. ${ }^{6}$ Roman je uz to oblik koji je sposoban s lakoćom uporabiti elemente drugih žanrova. Kritika uočava da je »roman rabio teme i ustroj slične onima iz tragične drame ${ }^{7}$. Leech zatim i nabraja neke od najvećih ostvaraja romanesknoga žanra i književnosti uopće pa uz ostalo spominje Anu Karenjinu, Crveno i crno, Gospođu Bovary, Mobyja Dicka i Lorda Jima.

Terence (Terry) Francis Eagleton dopušta elemente tragike u romanu, no nalazi i suprotne težnje. Glede Crvenoga i crnoga ističe tragični ekstremizam i ujedno olinjalost svakodnevna života: upravo u taj procijep propadaju Stendahlovi junaci. ${ }^{8}$ Balzacova su mu djela također puna tragedija pa spominje propast ohologa Luciena de Rubempréa i poniženja oca Goriota. Navedene i druge Balzacove tragedije ipak ukupno čine Ljudsku komediju jer, kako misli Eagleton, sve događaje uokviruje buržoasko društvo koje je robusno i puno života. Nešto je slično uočljivo i u Budakovu Ognjištu, gdje je Anerina tragedija samo poglavlje, istina bitno, u životu sela Sveti Rok. Mjesto se pokazuje otpornim na Blažićevo zlo i nastavlja neuništivo rađati svoju budućnost. ${ }^{9}$

Tematski modusi književnosti ne dopuštaju širok izbor. »U pripovjedačkoj smo književnosti otkrili dvije glavne tendencije: 'komičku' tendenciju prema uključivanju junaka u društvo i 'tragičku' tendenciju prema junakovu isključivanju iz društva. $\ll{ }^{10}$ Girard piše slično o vrstama završetaka romana pa tumači da imamo ili junaka koji je nekad bio osamljen pa se zbližava s drugim ljudima ili junaka koji je bio društven, a na kraju zadobiva samoću. ${ }^{11}$

\footnotetext{
${ }^{6}$ Usp. D. LODGE, The Art of Fiction, London, 1992., 62.

${ }^{7}$ C. LEECH, Tragedy, London, 1969., 31.

${ }^{8}$ Usp. T. EAGLETON, Sweet Violence, Oxford, 2003., 183.

${ }^{9}$ Godine 2014. Aneri je u Sv. Roku podignut brončani spomenik, djelo akademskoga kipara Slavena Miličevića.

${ }^{10}$ Usp. N. FRYE, Anatomija kritike, Zagreb, 1979., 68.

${ }^{11}$ Usp. R. GIRARD, Struttura e personaggi nel romanzo moderno, Milano, 1965., 253.
} 


\section{Molitelj}

Središte komičnoga ugođaja u komediji biva bomolohos, lik predstavljen u robu Palestrionu iz Plautova Hvalisavoga vojnika, Držićevu Pometu, Molièreovu Jacquesu i La Flechèu iz Škrtca te Shakespeareovu Falstaffu iz Henryja IV. Suprotan lik $\mathrm{u}$ tragediji biva molitelj /suppliant/ u kojem se tragičan osjećaj ostvaruje u punoj mjeri. Ta je osoba slika bespomoćnosti, a primjer je Sofoklova Euridika iz Antigone, koja odlazi u smrt bez riječi. Zatim su tu Shakespeareove Ofelija, Julija, Cordelija te Desdemona. Molitelje predstavlja i Goetheova Margarete, Gretchen iz Fausta - $s$ time što u njoj naglašenije djeluje krivnja, pa su njezina majka i brat bliži toj odrednici. »U osobi molitelja sažaljenje i strah dovedeni su do najvećega mogućega stupnja intenziteta, a strahovite posljedice što ih snosi svatko tko je odbio molitelja središnja su tema grčke tragedije. $\ll^{12}$

Molitelj pripada široj obitelji pharmakosa ili, jednostavno, žrtava, a potvrdu nalazimo u teoriji tragedije Adriana Poolea. Četvrto poglavlje knjige naslovljeno je Koga okriviti?, a dio u tom poglavlju nazvan je Nalazeći žrtvenoga jarca. Poole uočava da u tragedijama djeluju različite vrste tih osoba te da je katkad u istoj tragediji nazočno više od jednoga takvoga lika. ${ }^{13}$

Prema podatcima koje pruža uglavnom Frye, a onda i Poole i Eagleton, možemo izvesti četiri temeljne osobine koje ima lik molitelja: a) ženska je osoba ili je u podređenom društvenom položaju ili ima obje osobine; b) prijeti joj nasilje; c) šuti u svojoj nesreći i ne uspijeva prenijeti obavijesti o svojoj pogibli; d) nije protagonist ni antagonist.

\section{1. ŽENSKO BIĆE S PODREĐENIM POLOŽAJEM}

Molitelj je donekle i Izak, a takav je lik i Jiftahova kći iz Sudaca, mlada žena i djevica. Vjerojatno su prvi pravi molitelji Staroga zavjeta egipatski prvorođenci. Po rečenici koja govori da su Mojsije i Aron izveli sva ta znamenja pred faraonom (Izl 11, 10) zaključujemo da je ovaj znao za prijetnju - nitko međutim nije upozorio ni pitao prvorođence za stav o mogućem spasu ako oni koji odlučuju puste Izraelce. Očita dragovoljnost s naglašenim domoljubnim iskazima sreće se pri kraju Euripidove Ifigenije na Aulidi. Shakespeareova Ofelija također pada na društvenoj ljestvici; Cordelija i Lear vode stranu vojsku, a njezinim bi dobitkom Cordelija postala vladarica, no njihova će vojska biti poražena. Lizaveta Ivanovna iz Zločina $i$ kazne nije samo žena u muškom svijetu, ona je podređena i polusestri lihvarici.

\footnotetext{
${ }^{12}$ Usp. N. FRYE, Anatomija kritike, 246.

${ }^{13}$ Usp. A. POOLE, Tragedy. A Very Short Introduction, Oxford, 2005., 52.
} 
Anera je žena, a muškarci su u Svetom Roku povlašteni. Najbolnija je činjenica da muževi tuku žene. ${ }^{14} \mathrm{U}$ tome prednjači negativac Blažić koji nemilice diže ruku na Mandu, a jedan je od razloga očit: $\gg$ Ipak je sigurno da bi mnogi njegov udarac na Mandina leđa bio blaži, mekši i lakši, da nije bilo one žetve... « ${ }^{15}$ Blažić je naime kroz košulju vidio Anerine grudi i otada je njome bolesno obuzet. Negativni stavovi prema ženskomu rodu u cjelini stavljaju se također na Blažićevu dušu. ${ }^{16}$

U selu djeluje i znakovito imenovanje. »Žene« bivaju stavljene u oprjeku prema $\gg$ ljudima $\ll$, a ta imenica označuje muškarce: $\gg$ Mara je ispod oka promatrala Lukana, s koliko ljubavi, pažnje i pobožnosti slaže cjepanicu do cjepanice, i to on - koji inače nije nikada naložio vatre. To je ženski posao, a za ljude je, da dovezu drva iz Velebita, da ih nacijepaju - i ništa više. $\ll{ }^{17}$

Muška dominacija ipak nije apsolutna. Vatru za ognjište pali samo žena, a moramo znati da je ognjište znak za obitelj. U opisanoj seoskoj zajednici obitelj je zapravo svetinja, vjerujem da bi mnogi rekli i fetišs, koja je blizu važnosti što ju imaju metafizička bića. Zanimljiva je još jedna antropološka i folkloristička pojedinost. Temeljni je problem sela visoki mortalitet djece pa i Jela vidi da od desetero djece $\gg$ jedva nekoliko obuje ljudsku obuću $\ll^{18}$. Potomstvo je stoga dragocjeno, ali muškarci ne smiju držati dijete u svojim rukama. ${ }^{19}$

Obitelji u Svetom Roku s početka XX. stoljeća žive u zadrugama, koje redovito imaju gospodara. Glava takve zajednice ne mora biti muško, što je prikazano u situaciji prvotne Lukanove obitelji u kojoj su on i brat mu Zekan bili djeca, a gospodarica je majka Marija.

$\gg$ Otac im umrije, kad je Josi bilo osamnaest godina, pa sva kuća i gospodarstvo padoše na glavu majci Mariji i njemu kao najstarijoj muškoj glavi. Gospodar je zadruge tada bila Marija i zadržala gospodarstvo u svojim rukama, dok nije svu djecu poudala i poženila. Bila je bistra i okretna, prometljiva i gospodarna ... $\ll^{20}$

${ }^{14}$ Lika XIX. i XX. stoljeća koju prikazuje Budakov opus poznaje i okolnosti u kojima žena tuče, točnije batina muškarce (usp. M. BUDAK, Hajduk, Zagreb, 1945., 41.), a spominje i situacije obiteljskoga nasilja u kojima žena isprebija muškarca (usp. M. BUDAK, Bazalo, Zagreb, 2004., 275.). Tema obiteljskoga nasilja, sa stavom lika koji je blizak središnjoj inteligenciji, prikazana je i u romanu San o sreći: »Pravi čovik ne tuče svoju ženu. Ako je dobra, ne će zaslužiti, ako li nije dobra, ne koriste batine.«(M. BUDAK, San o sreći, Zagreb, 1940., 191.). Time se i Blažić povratno osuđuje.

${ }^{15}$ M. BUDAK, Ognjište, Zagreb, 1990., 30.

${ }^{16}$ Usp. isto, 48., II.

${ }^{17}$ Isto, 24.

${ }^{18}$ Isto, 191., II.

${ }^{19}$ Usp. isto, 127., također usp. ISTI, Kresina, Zagreb, 1944., 342.

${ }^{20}$ Usp. ISTI, Ognjište, 30. 
Anera je iznimna žena, što je vidljivo u imenovanju, jer može biti ravna muškarcima, pa ju njezin djever Joso i naziva $\gg l j u d a \ll{ }^{21}$ a to čini i Lukan. ${ }^{22} \mathrm{U}$ romanu Kresina vrijednu i inteligentnu Iku također pohvali starješina Jukan tako što joj kaže: $\gg$ Mužko si, lipa moja nevista $\ll^{23}$, a onda će dobiti i naziv $\gg 1 j u ̂ d a ~ « .{ }^{24}$

Anera uživa u svojoj sredini veći ugled od niza muškaraca. Prije svega se to odnosi na antagonista, koji u selu nema pristaše osim starice koja je »samo baba Anđuša, ali je bolja nego itko $\ll{ }^{25}$.

Uz pripadnost ženskomu kolektivitetu, Anera je u dodatno podređenu položaju time što je iz izrazito siromašne obitelji. Blažić joj odmah na početku nalazi taj nedostatak u razgovoru sa suprugom Mandom. Kaže za nju da je $\gg$ golokraka «, samo kako bi nešto rekao, no činjenica siromaštva ostaje. Anera će biti siromašnom i nakon udaje, jer ju Blažić nije prihvatio u kuću.

Situacija će se posebno zaoštriti nakon što joj se voljeni suprug Mića ne vraća iz rata. Prikaz je pogođen: $\gg$ Toga je časa osjetila strahovitom, ubitačnom jasnoćom svu svoju bijedu i nesreću: ni pedlja zemlje, ni šake žita, ni zrna soli, ni struka konoplje ni čuperka vune $-\mathrm{s}$ dvoje nejake djece, a njega nema. $\ll^{26}$

Joso će shvatiti Anerin položaj kad usporedi veliki kotao za mast u svojoj kući i sitan lončić što ga ima Anera. »Ne, ne - odgovori ona, vadeći žlicom mast iz nekog malog, malog lončića u kakvom njihova majka kuha kavu. Josi dođe pred oči golemi ćup kao kaca, u kom majka drži mast, i postavi se kraj tog Anerina lončića: stajali su tu pred njim taj golemi ćup i taj sitni lončić. $\ll^{27}$

Anatomija kritike uči da se molitelj često nalazi »u tragičnom položaju izgubljenoga mjesta veličine $\ll{ }^{28}$. Vodeći je ženski lik Budakova romana izniman, pa već na početku djela o njoj razgovaraju supružnici Manda i Blažić kao o mogućoj nevjesti. Blažić to odbija stoga što ju i sam želi, a Manda kaže: »A unaka prava, vridna i lipa cura, da joj nema para u svoj Lici.« ${ }^{29}$ Dapače je i u očima budućega zločinca Blažića ona bila iznimna, pa tako misli i dok ju gleda među drugim žetelicama: »Sve su vrijedne, sve

\footnotetext{
${ }^{21}$ Isto, 133., II.

${ }^{22}$ Usp. isto, 171., II.

${ }^{23}$ ISTI, Kresina, 132.

${ }^{24}$ Isto, 133.

${ }^{25}$ ISTI, Ognjište, 169.

${ }^{26}$ Isto, 286.

${ }^{27}$ Isto, 297.

${ }^{28}$ N. FRYE, Anatomija kritike, 246.

${ }^{29}$ M. BUDAK, Ognjište, 10.
} 
su hitre, al je među svima Anera vazda najprva ( ... ). Najprva i najstasitija i najljepša (...). I najljepša, i najljepša. ${ }^{30}$

Anera se ne nada kraljevskoj veličini, nego bi joj ženidba s voljenim Mićanom i djeca te život u novoj zadruzi značili vrhunac sreće. Ovaj lik ima se pravo tomu nadati jer drugi likovi često o njoj govore da joj nema ravna, nema joj parice, kako se u djelu kaže. Roman prikazuje njezino teško poniženje, zapravo, pad jer ju svekar ne prihvaća u svoju kuću, što je bila sramota koja se u plovaniji nije dogodila nijednoj djevojci. ${ }^{31}$ Mladi par time gubi pravo uživati dobra u zajedničkom imetku zadruge. ${ }^{32}$

Kad mora nakon toga doći na Lukanovo polje kao najmenica, Anera $\gg$ Sada, ovog časa, osjeti da je strahovito uvrijeđena i ponižena, i taj joj osjećaj nagna suze na oči. ${ }^{33}$ Pomoć će joj dati činjenica da ima ljubljenoga čovjeka, ali će čitatelj uskoro dobiti obavijest o posebnom izvoru snage. Pripovjedač prikazuje Aneru u času njezina pada koji svi jasno vide i paze kako će se ona s time nositi. Iako joj drugi djelatnici na polju nisu neprijatelji, pa ju Lukanov sin Ducina i hrabri, ipak gledaju kako ona reagira. Kraj te scene moramo zastati. Pripovjedač je prikazao kako drugi seljaci ipak odmjeravaju Anerinu snagu nakon sramote koja ju je snašla. Onda je iskazao koliko se duboko uživjela u molitvu Očenaša uporabivši savršenu usporedbu: seljaci su u svojem srcu osjetili da Anera zna da se ispunjava Božja volja na nebu i na zemlji kao što zna da se ona zove Anera. Slijede zadivljene riječi onih pred kojima se molila, a na kraju imamo i završni dodir velikoga majstora. Lukanova je nevjesta Baruša kazala da sada razumije kako je Anera mogla podnositi nesreću. Pripovjedač spominje i mlado, nepismeno društvo koje sjedi oko palente, a okolo su im motike. Tada Lukan govori društvu misleći na Barušu: »Čujete li vi moga vilozova?! « Anera se ovdje nalazi u položaju Balzacove Madame de Beauséant iz romana Otac Goriot kad ju je napustio njezin voljeni markiz Miguel d' Adjuda Pinto, a ona mora upravo tada održati bal u svojoj kući.

Uskoro će na Aneru udariti i druge nesreće. Njezin se suprug nije vratio iz rata, a nema službene potvrde o smrti. Zlo je u tome što ju svekar ne prestaje napastovati, pa nalazi zaštitu u novoj zajednici s Lukanom. Anera će se međutim strmoglaviti i s toga drugoga životnoga uspona u brige i konačan pad - opet zahvaljujući Blažiću. Anera bi, zapravo, Mićanovim povratkom izgubila status stečen u životu s Lukanom. Antagonist laže da se Mića vratio, a Anera i Lukan na to naivno nasjedaju.

\footnotetext{
${ }^{30}$ Isto, 11.

${ }^{31}$ Usp. isto, 106.

${ }^{32}$ Usp. isto.

${ }^{33}$ Isto.
} 


\subsection{Prijeti joj NASilje I SMrT}

Molitelji nisu samo izloženi nasilju, nego njihova smrt nerijetko izgleda nepotrebnom. Sofoklova Euridika iz Antigone dobar je primjer s podređenošću stoga što ni na koji način ne sudjeluje u vlasti. $U$ oštroj je oprjeci prema protagonistici, uz koju se sila i spominje, što je nadahnulo Heideggera za interpretaciju koja je s razlogom izazvala kritike. ${ }^{34}$ Antigonina je smrt međutim puna smisla jer gubi život u izravnom sukobu s tiranskom vlasti. Ali čemu je koristila smrt Kreontove supruge Euridike?

Aneri prijeti nasilje od svekra Blažića, a ona je to razumjela u događaju kad joj se ovaj šulja oko kolibice u kojoj je ona zatvorena. ${ }^{35}$ Blažićev prvi napad, od kojega se žena obranila tako što je antagonista zarezala po licu njegovim nožem, prikazan je u cijelosti u romanu. Duboko zlo pojačano je time što joj Blažić najprije nudi novac, pa se čini da ju želi kupiti. Kratke rečenice i nizovi glagola pojačavaju dojam uzrujanosti i odgovaraju grčevitim, naglim pokretima u borbi.

»Nastane nijema, mukla, nemilosrdna borba. Nije se čuo niti jedan jedini glas. Ona se je otimala, lomatala, udarala koljenima i rukama, grebla ga i čupala za kose, a on ju je držao kao bijesan, kao čelikom, kao udav i dovukao je na krevet. U onom joj lomatanju padne ruka na džep njegova haljinca i osjeti pod prstima nešto tvrdo. Munjevitom brzinom zgrabi golemu britvu, očajnom snagom razmahne i kresne ga petom britve u obraz ispod lijevog oka. U istom času osjeti, da mu ruke popustiše. Povuče britvu iz rane, a krv šikne kao iz vola. Kako se je on bio navalio i nije odstupao, ona smjeri još jednom i krikne:

- Mića moj, Mića moj!

Blažić klone, ona ga gurne, otme se i ustane. $\ll^{36}$

Anera se obranila napadačevim nožem, a uskoro mu govori: »zakla’ ću te ka pivca $\ll$, pa Blažić odgovara da joj sada vjeruje. Ljubav prema pokojnomu suprugu toliko je moćna da ga hrabra žena zaziva u teškom času.

Čitatelj tada iznenađen vidi da Anera pomaže ranjenomu nasilniku. Zapravo je čudno koliko neobična scena izgleda uvjerljivo: žena zaustavlja krvarenje starom sinovljevom košuljicom, a onda rabi i stučenu žeravicu. Na taj čin kršćanske milosti zlo odgovara vrlo jasno: »Podivani’ ćemo mi još, veselje (...). Vidi’ ću ja još tebi

\footnotetext{
${ }^{34}$ Usp. M. HEIDEGGER, Introduction to Metaphysics, New Haven, 2000., 168., 174.; usp. C. P. GEIMAN Heidegger's Antigones, u: R. POLT, G. FRIED (ur.) A Companion to Heidegger's Introduction to Metaphysics, New Haven, 2001., 170.

${ }^{35}$ Usp. M. BUDAK, Ognjište, 267-271.

${ }^{36}$ Isto, 68., II.
} 
košuljicu.« Blažić će prijetnje doista ostvariti nakon već prikazana lukavstva, kojim zaštitnika Lukana šalje na željezničku postaju, a Aneru opet u kolibicu gdje se prvi napad bio dogodio. Anerine slutnje zla koje dolazi, slutnje kojih jedva da je i sama svjesna, bivaju samo jednim od pregršti prvorazrednih motiva u romanu. Njezin oproštaj s djecom, posebno s Vidukom, predstavlja sjajan primjer dramatske ironije i tragične rječitosti onoga što nije izrečeno. ${ }^{37}$

\subsection{NE MOŽE GOVORITI / PRENOSITI BITNE OBAVIJESTI}

Euridika iz Antigone odlazi u smrt bez riječi, a izvrstan je primjer moliteljske šutnje Shakespeareova Cordelija iz Kralja Leara. Ona izgovara u cijeloj drami samo 115 redaka. Nakon što se njezine sestre natječu u laski pred ocem, što je uvijek moderan šport, Cordelija izgovara dobro znane riječi, ali ih kazuje za sebe, a ne tako da svi čuju: ona može samo šutjeti i voljeti, »Love and be silent.« $(\operatorname{Lr} 1.1 .61)$. Ofelija također šuti pred Hamletom o tome kako su joj otac i kralj naredili da ga uhodi. Takav postupak vodi prema određenoj razini krivnje u molitelja. Naravno da se o tome može raspravljati i u Anerinu slučaju. Naime ona šuti o pokušaju zločina koji smo prikazali na kraju prethodnoga odlomka. Dapače, čujemo opet začuđeni kako govori nakon pokušaja odvratnoga čina: »I da znaš, o ovome ću šutit radi moga Miće, radi ognjišta i Boga, al ako mi plane ovo slame nad glavom, vrcom ću džandarim i prise ću prid Raspetim, da si je ti zapalije. $\ll^{38}$

Anerin je postupak pogrješan s dvaju stajališta, a prvo pruža čista logika. Lik kojega učestalo hvali njegova sredina zbog pameti čini posve nerazuman potez. Blažić je ohrabren njezinim stavom i još u istoj sceni prijeti ženi novim susretima. Drugi je prigovor još ozbiljniji, a tiče se prava ili, kako bi se danas reklo, pravne države jer prikrivati zločin znači podupirati zločin.

Korisno je raščlaniti razloge zbog kojih se Anera odlučila na šutnju. Spomen supruga Miće, koji se u to vrijeme već dugo ne vraća iz rata, mogao bi značiti dvije pojedinosti. Prvo, ne želi produbljivati zavadu između oca i sina te ne želi da sramota zbog pokušaja silovanja koji je izveo njegov otac padne i na Mićinu glavu. Zanimljiv je i drugi razlog, naime ognjište. Naravno da žena pod tim misli na cijelu Blažićevu obitelj, i to ne samo onu koja u tom vremenu živi nego i na pretke i na potomke. Anera će poslije u tom surječju i spomenuti vrijednoga djeda Vidurinu. Ognjište, zapravo, šira obitelj, postaje zamjenom za pravnu državu, koja u svijetu što ga roman prikazuje ipak djeluje: Blažić želi postati samovlasnikom, no službenici na općini to mu ne dopuštaju.

\footnotetext{
${ }^{37}$ Usp. isto, 287., II.

${ }^{38}$ Isto, 70., II.
} 
Anera je i izravno, poput prije navedene Cordelije, spomenula šutnju u razgovoru s djeverom Josom. Kad joj je kazao da ne razumije zašto ju otac Blažić nije htio primiti u kuću, ona kaže da ni ona ne zna - iako to nije posve točno - ali na kraju dodaje: $\gg \mathrm{Al}$ što mogu, man trpiti i mučati i nositi do svoga groba ... $\ll^{39}$

U obzoru Anerine šutnje, posebno je bitan međutim razlog koji ovu osobu određuje kao molitelja, a ne kao protagonista. Držim da je svijest o toj pojedinosti korisna svima koji se sretnu sa zlom te mislim da je na određeni način djelovala u lijepoj Aneri i nakon samoga prvoga Blažićeva napada. Riječ je o blokadi, o stresu koji koči tijelo i um te na koji zločinci katkad također svjesno ili nesvjesno računaju. Pogledajmo što se zbiva prije same prve borbe:

»- Razumin ja, 'rankane, al budi pametna! - reče on ljubazno, metnu ruku na njezino koljeno, držeći novac palcem i kažiprstom. Ona osjeti njegovu ruku kao usijano željezo i oćuti neodoljivu potrebu, da se izmakne, no jednostavno nije smogla snage. Bila je ukočena, sleđena, začarana - što li, te nikako nije mogla prenijeti misli na mišičje i pomaknuti se. ${ }^{40}$

Anera će se u nastavku scene krvavo i odlučno braniti, no čini mi se da je određena ukočenost misli nastavljala djelovati u njoj i nakon borbe. Stoga, zbog te svoje ljudske, ako ne i ženske slabosti, ona nije smogla snage reći što se dogodilo.

Anera ipak nije upravo u cijelosti šutjela. Kad je zaprosila Lukana očito je mislila i na svoju zaštitu. Ona je rekla čovjeku u kojemu vidi budućega muža da ima velikoga neprijatelja, a to je njezin svekar, »rode $\ll \mathrm{u}$ svetoročkom govoru. Anera govori čas prije negoli će predložiti brak Lukanu: »- Ja ću tebi reći, striče, i ko' j’ taj moj dušmanin, pa š me unda morda bolje i lakše razumiti. To j’ moj svekar.« Onda će ga podsjetiti na događaj u kojem je došao u njezinu kolibicu upravo u času kad se Blažić opet spremao napasti, da bi rekla i sljedeće: »-Eto vidiš, moj striče: zato ću ja u svojoj kolibici morati spavati sa sikirom pod glavom. $\ll^{41}$

U dogovoru oko toga što jedno drugomu mogu dati Anera opet spominje nesreću koja joj prijeti i od koje očekuje da će ju Lukan braniti: $\gg S$ ovim, što nam ostaje, moremo biti zadovoljni i ti i ja: ja ću moći mirno spavati bez sikire pod glavom, a ti ćeš imati koga ostaviti na ognjištu. $\ll{ }^{42} \mathrm{Je}$ li ona očekivala da će Lukan razumjeti ono bitno i bez da mu ona izravno sve kaže? Situacija oko seksualnosti može zbunjivati jer je Lukan, čini se, već prije bio shvatio Blažićeve namjere. »Sad mu je sve jasno:

\footnotetext{
${ }^{39}$ Isto, 112., II.

${ }^{40}$ Isto, 67., II.

${ }^{41}$ Isto, 250., II.

${ }^{42}$ Isto, 251., II.
} 
on je zaćorio i sprcao na Aneru kao pašče, a Anera kao Anera - odmah sve osjetila, pa se toga i drži. «3

\subsection{Molitelj NiJe PRotagonist}

Moliteljice iz velikih Shakespeareovih, Goetheovih i Dostojevskijevih djela imaju još jedno zajedničko obilježje: nisu vodeći junaci. Teorija proze uviđa da nije uvijek jednostavno odrediti tko je vodeći junak djela, pa se utjecalo i činjenici pojave u naslovu. Budakov roman biva u tom obzoru školskim primjerom jer je autor imao prvotno namjeru roman nazvati Anerina kolibica. ${ }^{44}$ Konačni naslov Ognjište, koliko god govorio o važnosti doma i obitelji na općoj razini, ipak, prije svega svjedoči o Lukanovu ognjištu.

Maria (Mieke) Getrudis Bal uvodi pet kriterija odredbe heroja ili heroine, koje ćemo ukratko predstaviti: kakvoća / qualification/ (misli se na pojavnost u tekstu: opsežne obavijesti o izgledu, psihologiji, prošlosti itd.); raspodjela /distribution/ (vodeći se junak javlja često i na važnim mjestima); samostalnost /independence/ (javlja se samostalno ili monologizira); uloga /function/ (poražava suparnike ili razotkriva izdajice); odnosi /relations/ (ima relacije s najvećim brojem drugih likova). ${ }^{45}$ Anera ne ispunjava samo kriterij uloge jer ona ne poražava zla Blažića, to mora učiniti pravi protagonist Lukan. U idućem dijelu teksta podrobnije ćemo prikazati Anerina obilježja u svjetlu prethodnih distinkcija.

Mieke Bal nije jedina kritičarka koja vidi da količina prostora posvećena liku biva odrednica njegove važnosti. ${ }^{46}$ Protagonist ne mora uvijek imati etiku na svojoj strani, sjetimo se samo Macbetha, Eme Bovary ili Humberta iz Nabokovljeve Lolite. No ipak je najčešće moralna odrednica na strani vodećega junaka - unatoč mogućoj hamartiji, koja u tragedijama biva pravilom i dio je junakove karakterizacije. Aneri je doista posvećeno mnogo prostora, navest ćemo samo neke primjere: vidimo kakve su joj oči, naime goleme, usijane i crne, pa njima Blažiću upali i dušu i mozak; ${ }^{47}$ prikazane su i njezine grudi kojima ga je zapravo i začarala, iako to nije htjela, a riječ je o samo jednoj iz niza savršenih scena u romanu; ${ }^{48}$ doznajemo kakva

\footnotetext{
${ }^{43}$ Isto, 165./166., II.

${ }^{44}$ Usp. S. PETROV, Naša patnička nerazorena ognjišta, u: Z. MARIĆ, Zbornik radova o književniku Mili Budaku, Split, 1998., 84. Prvotno objavljeno u Novoj reviji 17(1938.)5, 388-401.

${ }^{45}$ Usp. M. BAL, Narratology, Toronto, 1985., 132.

${ }^{46}$ Usp. A. WOLOCH, Minor Characters, u: F. MORETTI (ur.), The Novel, II, Princeton, 2006., 300.

${ }^{47}$ Usp. M. BUDAK, Ognjište, 9.

${ }^{48}$ Usp. isto, 11.
} 
je bila već u djetinjstvu; ${ }^{49}$ opisana je njezina marljivost i zdravlje njezina roda. ${ }^{50} \mathrm{Na}$ lazimo i cijele dijelove koji su pruženi iz Anerina očišta, pa je iz njezine perspektive prikazan dio ludila u koje zapada Ducina, ${ }^{51}$ a njezino oko i njezin stav prisutni su i u potresnoj sceni pokušaja silovanja. Roman donosi i njezine misli, kako je to bilo već kazano, pa jasno vidimo kako se osjeća kad joj se Mićan ne vraća iz rata te kad meditira bi li nešto rekla o strašnoj pogibli koja joj prijeti od Blažića.

Anera je u središtu nekoliko izvrsnih scena, a uz spomenuti prikaz žetve, kad joj Blažić vidi grudi i sam prvi pokušaj silovanja te upravo savršen prikaz molitve pred drugim djelatnicima, moramo dodati i cijeli niz situacija u kojima je ona predmet razgovora. O njoj razgovaraju na početku Manda i Blažić kao o mogućoj sinovljevoj supruzi, a zanimljivo je da i Lukan odmah savjetuje tada još budućemu neprijatelju da ju prihvati kao nevjestu. ${ }^{52}$

Ipak je dobro znati da dijelova s prikazom nutrine imaju i drugi likovi, poglavito Blažić i Lukan. Jasan uvid u stanje duše, prikaz svoje psihe, pa onda i samo očište dobiva i prateći (sporedni) lik Joso. Dapače je njegov ukupan odnos s ocem Blažićem možda i najbolji niz digresija hrvatske književnosti, u kojima je, zapravo, sve savršeno: prikaz simbola tise, teške slutnje majke Mande, mladićev iskaz o tome da voli oca, Josino spašavanje oca koji ga misli ubiti pa onda scena kad pred njega istupa sa svojom voljom. ${ }^{53}$ Pogođena je i sama epska retardacija koja se time postiže, a koja funkcionira i unutar prikaza događaja iz digresija.

Mislim reći da Anera nije jedini plastično i moćno prikazan lik, iako je posve točno da ona u nizu elemenata dominira. Sama činjenica da je predmet žudnje tolikih bitnih muških likova i da ona te žudnje uspijeva kanalizirati u svima osim u jednom, kobnom Blažićevu slučaju, čini ju posebnom. Držim da je način kojim odbija Josinu prosidbu, zapravo, izvrstan primjer inteligencije. Ona mu odmah nakon toga nalazi posao, jer ne želi da bude uvrijeđen, pa se dogovaraju kako će joj urediti »mali krović nad vratima, nad pendžericu metniti 'ednu daščicu $\ll^{54}$.

Uz sve rečeno, Anera ipak nije protagonist romana. U djelima s oštrom polarizacijom i teškim sukobom dobra i zla, kakvo jest Ognjište, tipični protagonist najčešće zadaje odlučan udarac zlu ili barem to pokušava učiniti - Bal kaže da poražava suparnika. Kad i stradava u odlučnoj borbi, protagonist biva moralnim pobjednikom.

\footnotetext{
${ }^{49}$ Usp. isto, 53.

${ }^{50}$ Usp. isto, 80.

${ }^{51}$ Usp. isto, 317-320.

${ }^{52}$ Usp. isto, 92.

${ }^{53}$ Usp. isto, 57-58., II.

${ }^{54}$ Isto, 390.
} 
Točno je da protagonist književnoga djela ne mora ostati na pozornici ili u očištu pripovjedača upravo do kraja djela. Glede prave tragedije, primjer je Antigona koja odlazi u smrt u 944. retku šestoga čina, s riječima da je izvršila svoju svetu dužnost. Tragedija se nastavlja do kraja toga čina i u cijelom sedmom, a djelo ima ukupno 1353 retka. Drama Antigona nakon smrti protagonistice postaje tragedija osvete, a kletva koju je izgovorila moćna djevojka ubija njezina neprijatelja nakon njezine smrti.

Iako nije riječ o djelu s oštrom razlikom dobra i zla te $s$ teškom borbom, zanimljiv je i završetak možda najcjenjenijega romana književnosti uopće, Tolstojeve Ane Karenjine. Već naslov govori o tome tko je središnji lik, no ta osoba ne ostaje u očištu do kraja djela. Možda joj se tek jednim dijelom i umanjuje vrijednost time što se prikazuje drukčiji način odgovora na gubitak jedine, velike i prave ljubavi. Levin razumije da bi njegova supruga Kitty Ščerbacki bila radije izabrala drugoga i sve do kraja djela teško uspijeva naći pravu životnu ravnotežu. No na kraju ipak doživljava neku vrstu kršćanskoga satorija u poruci po kojoj ne valja živjeti za sebe, nego za Boga. S druge strane Anin se ljubavnik Vronski neuspješno pokušava ubiti pa u tome biva ponižen u odnosu na ženu koja ga je voljela. Ipak, dok odlazi kao dobrovoljac u rat, muči ga, naravno, misao na Anu, ali ga ujedno boli zub i to mu usta puni slinom - kao da je i protagonistica ponižena tom nezgodnom usporednošću. Bitno je da Ana, i tako ponižena, ostaje važna u svijesti likova, prije svega kao kontrast pozitivnomu Levinu i negativnomu Vronskomu. Oba muškarca ne pobuđuju onoliko sućuti i usredotočenosti prikaza pripovjedača koliko je to činila Ana.

Pogledajmo kakav je Anerin položaj u tom smislu. Anera je ubijena pri početku XXV. poglavlja romana koji traje još tri poglavlja, do XXVIII. Prema izdanju kojim se služim, idući događaji ispunjavaju 92 stranice, od ukupno 822 što ih broji djelo. Nije riječ samo u količini prostora nego o tome što roman sada tek manjim dijelom poprima obrise tragedije osvete. Čitatelj bi taj žanr svakako mogao očekivati pa bi Ognjište bilo u tom smislu nalik Hamletu i Antigoni. Blažićev usud međutim nije onako sigurno zapečaćen kako je bio Kreontov, nego je potrebna osoba koja će $\mathrm{mu}$ se suprotstaviti. Lukan sada odlučno stupa na pozornicu, točnije u očište pripovjedača u punoj snazi, pa uz ostalo mirno dokazuje po građenom rupčiću da je Blažić ubojica. Tekst uspijeva na intrigantan način odgađati sam čin pravde. Lukan, naizgled tek po pravilima žanra tragedije osvete, kao da oklijeva s tom pravdom. Posljedica na ustroj teksta biva razvučenost, koju je i rana kritika dobro uočila: Blažićevo je uništenje »razvučeno « a isti autor napominje: $\gg \mathrm{Za} \mathrm{moj} \mathrm{ukus} \mathrm{otegnula}$ se je četvrta knjiga u romantičkoj sceni nad turskim avanom. ${ }^{55}$ Budakov je tekst moguće opravdati na tri načina, a prvi je epska retardacija, koja mora povećati na-

${ }^{55}$ A. BONIFAČIĆ, $\gg$ Ognjište « Mile Budaka, u: Hrvatska revija 12(1939.), 91-94. 
petost $\mathrm{i}$ iščekivanja čitatelja. Drugi razlog držim jačim: roman je tek jednim svojim žanrovskim dijelom tragedija osvete, a u njoj protagonist mora oklijevati s osvetom: »obećanja, dug časti i krvne relacije koje oblikuju Hamleta i ostale uključuju sustav osjećaja što vode iznad izravne akcije. ${ }^{56}$

Međutim u Budakovu romanu djeluje i treće obrazloženje te razvučenosti, koje ide iznad uobičajena oklijevanja osvetnika iz tragedija osveta. Naime Anerina se važnost nakon njezine smrti stalno i naglo smanjuje time što protagonist mora zapravo braniti samoga sebe od antagonista. Kao da bez te agresije na sebe ne bi bio učinio ono što bi mu po čistoj pravdi, pa i po ustroju tragedije osvete, bila dužnost provesti. Čitatelj može biti s pravom ili sa zadovoljstvom opet začuđen time što je Lukan spreman oprostiti Blažiću: »Muči se u žalosti i tuzi i još misli - da oprosti. ${ }^{57}$ Riječ je o tome da Ognjište nakon Anerine smrti iznenađuje u žanrovskom smislu. Kad sve pokazuje da će roman krenuti poznatim putovima tragedije osvete, zbivaju se dvije mijene u žanru, a obje odvode djelo od obilježja tragedije osvete. Anera je pokazala bijes kad je pljunula Blažiću u lice nakon njegova upita bi li spavala sa svojim svekrom.$^{58}$ Kritika osuđuje taj postupak s moralne strane, pa govori o sjeni na liku uzorne Anere. ${ }^{59}$ Ogorčen je čin međutim mogao biti najavom bijesa koji je očito obilježje tragedije osvete. ${ }^{60}$ Tomu bijesu valja dodati i činjenicu da Anera spominje sjekiru kad Lukanu govori o svojem nesretnom svekru Blažiću. Samo što se u Budakovu romanu taj bijes jednostavno stišava razvojem djela. Dapače, nakon Anerine smrti on ne prelazi na mogućega osvetnika Lukana. Taj je lik savršeno miran i pomno planira Blažićevo ubojstvo koje u svojoj biti i nije osveta za Anerinu smrt. Lukan ubija Blažića stoga što ovaj misli ubiti njega. Bitna za odredbu protagonista biva činjenica da Anera - za razliku od pravih protagonista koji to redovito čine u djelima s oštrim sukobom dobra i zla - sama nikako ne zadaje posljednji udarac Blažiću. Ne osjećamo da je neka njezina tajanstvena nazočnost nakon smrti zaustavila zlo, pa ni to da je misao na nju potaknula protagonista Lukana na aktivnost. Aneri se stalno umanjuje važnost, o njoj se ne govori mnogo, dapače, drugi ženski lik stupa na njezino mjesto i time opet i opet uspješno iznenađuje čitatelja. Uloga konačnoga pobjednika pripada Lukanu, a njegova posljednja pratiteljica ne će biti Anera, nego drugi ženski lik. Hamlet je stradao u sukobu s Klaudijem, ali ga je porazio. Konačni udarac zlu ne zadaje ni možda najčišći molitelj u književnosti, naime Cordelija iz

\footnotetext{
${ }^{56}$ J. KERRIGAN, Revenge Tragedy, Oxford, 1996., 7.

${ }^{57}$ M. BUDAK, Ognjište, 380., II.

${ }^{58}$ Usp. isto, 164., II.

${ }^{59}$ Usp. V. NIKOLIĆ, »Ognjište«: roman Mile Budaka, u: ISTI (ur.), Mile Budak pjesnik i mučenik Hrvatske, Barcelona - München, 1990., 110.

${ }^{60}$ Usp. J. KERRIGAN, Revenge Tragedy, 112-113.
} 
Kralja Leara. Zlo će poraziti Edgar i Albany. Pravi protagonist Lear ostaje na sceni praktično do kraja, nakon njegove smrti ostaje samo epilog.

Ali događaji u Ognjištu nakon Anerine smrti nisu samo epilog, riječ je o cijelom nizu novih pojedinosti koje s Anerom nikako nisu povezane. One uporno jačaju pravoga protagonista, istodobno naglašavaju rast posve drugih žanrova, a smanjuju obilježja žanra tragedije osvete u romanu. O tome možemo govoriti na nekom drugom mjestu, ovdje ćemo tek navesti romansu kao konačnu odrednicu djela.

Anera kao moliteljica i time elementi žanra tragedije - a onda i drugi žanrovi koje Ognjište u sebi pomno izgrađuje - govore o tome da ovaj roman ipak ima uzore u stilsko-formalnom pogledu. Samo što su oni dobro elaborirani i uz to uklopljeni u tkivo romana prvorazrednom ambijentacijom, smještajem u svetoročko okružje prve polovice XX. stoljeća, pa ih nije lako opaziti. Stoga se ne bih mogao složiti s Marakovićevom suprotnom tvrdnjom, iako je njegov tekst inače doista vrijedan. ${ }^{61}$ Pod vrijednošću mislim uz sve ostalo na misao o vertikali prikaza ljudskih duša, u rasponu od Blažićeve do Anerine, a onda i isticanje jednoga od ključnih razloga velikoga uspjeha romana: »neodoljiv dojam života, doživljenosti $\ll{ }^{62}$.

\section{Anera: obilježja junakinje}

Kako je vidljivo iz prethodnoga izlaganja, dobro je odrediti razliku između junaka i vodećega junaka, znači protagonista i važne, ali ipak ne i vodeće osobe djela. Držim da je Anera junakinja, ali nije vodeća junakinja. Upravo po tome što ima niz obilježja protagonista ona je posebna među moliteljima svjetske književnosti. Ne tvrdim da je samim time ujedno i bolji lik, no biva očitim da je pomno elaborirana, da joj je pruženo mnogo mjesta u romanu i da može konkurirati za mjesto protagonistice što ona ipak nije. $S$ druge strane držim da nije teško dokazati kako Anera jest važna, a za to bih se poslužio odrednicama koje pruža Lynette Porter. ${ }^{63}$

\subsection{Djeluje po SVOjim uvjerenjima}

Obilježja iz ovoga poglavlja obuhvaćaju Anerine razlike u odnosu na situaciju u selu Svetome Roku, zatim razlike u odnosu na katoličke propise, a govorit ćemo i o tome kako ju odluke približavaju protagonistu Lukanu.

${ }^{61}$ Usp. LJ. MARAKOVIĆ, Ognjište, u: Z. MARIĆ (ur.), Zbornik radova o književniku Mili Budaku, 164. [prvi puta objavljeno u Hrvatskoj prosvjeti 26(1939.)].

${ }^{62}$ Isto, 169.

${ }^{63}$ Usp. L. PORTER, Unsung Heroes of The Lord of the Rings, Westport, 2005., 20. Obilježja junaka iz idućih odlomaka pružena su po navedenom izvoru. 
Anera se razlikuje od svoje okoline po svojem izgledu jer joj je ljepota uvelike posebna, što smo već prikazali. Izdvaja se i inteligencijom, što je zabilježeno na nizu mjesta u djelu. ${ }^{64}$ Nadalje, nju s Mićanom povezuje neobična ljubav, koja kao da se je s njima rodila: »Ja mislim da smo se mi s tim i rodili. (... ) Bila sam mali curenjak, al sam se već onda volila sa svojim pokojnim Mićanom. Nismo mi to znali, al je to bilo. I kako je unda bilo i kako j' bilo, kad smo se uzeli, tako j' u meni i danas. ${ }^{65}$ Takvih izraza međusobne ljubavi između Mićana i Anere ima mnogo u romanu. ${ }^{66}$

Anera se ne razlikuje od okoline samo po neobičnoj ljubavi prema Mićanu nego i po svojim stavovima. Razlika djeluje u doba kad je djevojčica, kad biva djevojka pred udaju i kad je udovica. Tako druge djevojčice puštaju da ih dječaci komušaju, znači da se s njima povaljaju i da ih možda štipaju i pipkaju preko odjeće, ali očito ništa više od toga. Pripovjedač kaže da od toga nikada nije bilo nikakva zla $\gg$ niti je kada zlo nastalo $\ll^{67}$. Međutim je Anera i u tome posebna pa se dječacima suprotstavlja is njima se tuče, najviše zbog ljubavi prema Mići. ${ }^{68}$ Pri tome rabi izvrstan izraz jer kaže da ona nije $\gg$ općinska kruška $\ll{ }^{69}$ - znači da ju dječaci ne mogu komušati kad se sjete.

U djevojačkom dobu sestre ju nagovaraju na udaju u kojoj su bitni kriteriji ljepota izabranika i njegovo imovinsko stanje. Anera i to odbija, i to žestoko i duhovito, jer kaže sestrama da nije ni kokoš ni krava, znači da ne gleda na imanje. ${ }^{70}$ Napokon, kad razumije da ju samo Lukan može zaštititi od Blažića te da je on pošten čovjek kojemu bi pomogla u njegovoj nesreći kad su mu umrla i djeca i unuk, ona zapravo prosi njega, što je neobično i u suvremenom svijetu. »- Reci ti meni striče, otvoreno ka' svome ditetu - ništa meni od tebe ne će biti ža', pa mi reci - a vidiš, striče, ja sam i žena, pa mi reci, kad sada sve razumiš, bi li ti mene vinča' ovaku, kakva sam? $\ll^{71}$

Anera tri puta opetuje reci mi, čime s jedne strane možda pokazuje svoju uzrujanost u tom času, ali i svjedoči o tome da je odlučna i da zahtijeva nedvosmislen odgovor.

Rana kritika otvorila je upite o tome je li moguće Budakovo djelo nazvati katoličkim romanom. Ivo Lendić kaže da ne možemo nazvati djelo izrazito katoličkim romanom stoga što je ljudska bijeda u njemu iznesena na snažan i sugestivan način,

\footnotetext{
${ }^{64}$ Usp. M. BUDAK, Ognjište, 53., 268., 71., II.

${ }^{65}$ Isto, 247., II.

${ }^{66}$ Usp. isto, 99.; 246.; 360.; 17., II; 72., II; 210., II.

${ }^{67}$ Isto, 317.

${ }^{68}$ Usp. isto, 360.

${ }^{69}$ Isto, 318.

${ }^{70}$ Usp. isto, 315.

${ }^{71}$ Isto, 250., II.
} 
$\gg$ ali i premalo diskretan $\ll^{72}$. Ipak nalazi u njemu više proživljenoga katolicizma i umjetničke religioznosti no u bilo kojem drugom romanu novije hrvatske književnosti, uz iznimku Cihlarovih Vukova.

Stanko Petrov također ističe dvije pojedinosti iz Anerina života koje su u očitoj suprotnosti s učenjem Katoličke Crkve. Ona živi s Mićanom prije nego što ih je plovan oženio. Nadalje, nakon što se Mićan ne vraća iz rata, ona predlaže brak Lukanu, a kad se brak po crkvenim propisima ne može ostvariti, jer nema dvaju svjedoka da je Mićan doista mrtav, oni žive nevjenčano. Istina, napovijedali su se u crkvi i zajednica u Svetom Roku vidi u njima muža i ženu, no u očima Crkve to jednostavno nije tako. »Glavna odgovornost za jednu i za drugu anomaliju pada na Aneru «, drži Stanko Petrov. ${ }^{73}$

Najveća je razlika Anerinih uvjerenja u odnosu na tradicionalan katolički moral rečenica koja mora iznenaditi i time u smislu očuđenja povećati vrijednost djela. Anera je naime izjavila da bi ona rodila Lukanu djecu i kraj živa Mićana. ${ }^{74}$ Dubravko Jelčić dobro pokazuje kakve upite otvara izreka: »Je li to moralni prijestup ili neki viši, uljuđenom čovjeku nepojmljivi oblik moralnog osjećaja u nekom nedokučivom elementarnom izdanju? $\ll^{75}$

Vinko Nikolić misli da su iskaz s rađanjem djece Lukanu te situacija u kojoj pljuje u obraz Blažiću ${ }^{76}$ sjene na Anerinu moralnom liku. ${ }^{77}$

U obzoru odnosa prema katolicizmu, valja istaknuti i rečenicu koja s jedne strane može začuditi, a s druge ju je lako razumjeti kad znamo da ju izgovara žena koja voli, a obraća se u mislima ljudima koji bi ju morali zaštititi od strašna nasilja koje joj prijeti od Blažića: »Spasite me, smilujte se duši mojoj, koja ne bi želila ni raja Božijega, kad i Mićan ne bi bije u njemu! $\ll^{78}$

Teško je zamisliti kršćansku sveticu koja tako govori, ali ženu od krvi i mesa, koja međutim ima svoj, jak i određen moralni kodeks, takvu je moguće vidjeti u navedenu izrazu.

${ }^{72}$ I. LENDIĆ, »Ognjište « Mile Budaka, Da li se Ognjište može nazvati katoličkim romanom?, u: Hrvatska straža 10(1938.)235, 4-6.

${ }^{73}$ S. PETROV, Naša patnička nerazorena ognjišta, 91-92. (prvi put objavljeno u Novoj reviji 17(1938.)5, 388-401.).

${ }^{74}$ M. BUDAK, Ognjište, 280., II.

${ }^{75}$ D. JELČIĆ, Povijest hrvatske književnosti, Zagreb, 2004., 393.

${ }^{76}$ Usp. M. BUDAK, Ognjište, 164., II.

${ }^{77}$ Usp. V. NIKOLIĆ, $\gg$ Ognjište «: roman Mile Budaka, 111-112.

${ }^{78}$ M. BUDAK, Ognjište, 215., II. 
Sličnost pravoga protagonista Lukana i vodeće ženske osobe romana Anere biva očita. Oba su lika označena blizinom zemlji, i to upravo istim riječima. Lukan: »ka crna zemljica $\ll^{79}$; Anera: $\gg$ jer je ona bila kao crna zemljica $\ll^{80}$. Time je diskretno istaknuta ne samo narav njihovih osoba nego i narav njihove povezanosti. Pozitivni Joso također je uspoređen s crnom zemljom. ${ }^{81}$ Lukan i Anera jesu ljudi koji su najbliže zemlji, a to znači obitelji i domovini. Sve što se čini za domovinu čista srca u obzoru svjetonazora iz romana dobro je i sveto, a poglavito su dobra djeca koja se rađaju.

Kad su Joso i Anera prolazili kraj Groblja, kako se lokalitet zove, Anera se prekrižila. Joso se pita zašto ona to čini, a heroina odgovara: »- Ako j' i tursko, groblje j' groblje.« Joso je i dalje začuđen, pa ju pita čini li to zbog straha, na što dobiva odgovor da se ona nikada ne križa od straha. ${ }^{82}$ Anera je ovdje pokazala toleranciju prema drugom u smislu kulture i vjere. Neka je ona pružena u vrlo rudimentarnom obliku, neka je dana i onima kojih na tom prostoru živih nema - ali je ipak još jedno zrnce u veličini te žene. Točno je da je književnik koji je lik stvorio mogao imati na umu svoju ideologiju, koja je naveliko promicala slogu katolika i muslimana u ime jedinstva hrvatskoga naroda. Samo, opet valja reći da je Anera posebna, svoja i velika. Kakav je u tom smislu Blažić, vidjet ćemo u tekstu o njemu. ${ }^{83}$

\subsection{MoŽE ISPlanirati STRATEgiJU, PA I U HODU DOK TRAJE KRIZA}

Anera je već u djetinjstvu pokazivala bistrinu i spomenutu inteligenciju. Kad joj Lukan i Anica nose suharke iz šume, govori im da joj ih ne stave upravo pred njezinu kuću, jer bi se netko mogao rugati; ne bi bilo dobro ni da ih Lukan odnese pred svoju pa da ona mora opet nositi, a drugi bi mislili da krade. Mora ih ostaviti na Raskrižju pa će ona poslije sama dalje sve učiniti. ${ }^{84}$

Redovit je pokazatelj određene vrste inteligencije humor. Vratit ćemo se na dvije scene u kojima Anera postupa po svojim načelima, a ne kako to čine druge djevojke iz prikazana prostora i vremena. Kad ju dječaci pokušavaju komušati, ona odgovara: »Nisam ja općinska kruška. $\ll{ }^{85}$ Žena ovdje brani ne samo pravo na svoj stav i svoje tijelo, ona ističe da je to potreba ljudskosti, upravo humanosti - ona nije biljka. Još

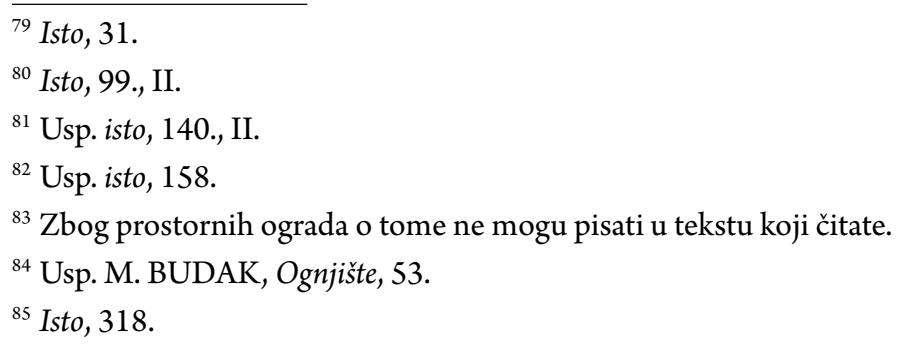


je zanimljivija u smislu duhovitosti i inteligencije konverzacija sa sestrama. Naravno, prethodna rečenica ovisi o tome kako ćemo definirati inteligenciju: ako je to smisao za bezočno iskorištavanje svake prigode u svoje materijalne svrhe, onda su Anerine sestre inteligentne.

>- Prosi' ćeš ti, jadnice, uz taku tvoju pamet.

- Sa svojim Mićom, ako j' Božja Volja.

- Vidi ćeš tu svoju ljubav, kad ne budete imali kore kruva!

- Unda - nije nigda ni bila ljubav!

- Koji je vrag upamtije tu nikakvu ljubav i benolije?! Iđe se na lip grunat i - da j' momak priličan. I - eto!

- Nisam ja ni kokoš ni krava. ${ }^{86}$

Sestre se rugaju spominjući pamet, rabe riječ vrag i niječu važnost ljubavi. Aneri je na ustima Božja volja, u srcu ljubav i, konačno, u riječima pogođen završni humorističan odgovor kojim neizravno imenuje svoje sestre. Opet je istaknula svoju ljudskost na samom kraju.

Glede toga da Anera zna smisliti strategiju u hodu, svakako se ističe njezin prijedlog braka Lukanu. On na to i ne pomišlja, iako bi ju svakako htio zadržati u kući, gdje mu je do smrti unuka pomagala u zadruzi.

Anera se dobro snašla i pri prvom Blažićevu napadu na sebe, jer ga je po licu zarezala njegovom britvom. Danas bi skoro svi kazali da je nakon toga trebala usmrtiti neprijatelja. No i Shakespeareov je Hamlet trebao prije uništiti svojega neprijatelja Claudiusa.

Vodeći ženski lik romana dobro smišlja strategiju u hodu i kad joj brak nudi neželjeni prosac Joso, brat njezina pokojnoga muža. Odbija ga tako što mu kaže da ga osjeća kao brata, a onda, kako sam rekao, pokazuje velik smisao za društvenu inteligenciju. Smišlja mu posao kako ga ne bi posve odbila od sebe. Dapače, ona mu ide isprositi buduću suprugu Kajanu.

\section{3. ŽRTVUJE SE AKO JE POTREBNO, ALI NE TRAŽI ULOGU MUČENIKA}

Čini se da Anera nekada upravo traži ulogu mučenika. Njezina želja za pomoći drugima i sućut prema svima prelaze granice ravnoteže. Možemo ju osuđivati kad pomaže Blažiću nakon pokušaja silovanja i možemo reći da nešto nije u redu kad

${ }^{86}$ Isto, 315. 
govori da bi rodila djecu Lukanu i kraj živa Mićana. Ali joj ne možemo zanijekati dosljednost.

Anera je bila spremna odreći se braka s Mićanom kad je shvatila da ju svekar ne želi primiti u kuću. Naime Mićan bi odlaskom iz zadruge izgubio veliki imetak, a ona je spremna toga se odreći. Mićan na to ne pristaje i oni su zajedno siromasi, u kolibici koju su im sagradili Mićanovi prijatelji.

Određenu žrtvu možemo vidjeti i u Anerinu pristupu poslu. Ona je siromašna i mora obavljati poslove kao najamnica, na tuđim njivama. Uostalom, u tom je statusu i ušla u Lukanovu kuću kad je ovomu umrla prva supruga i kad je izgubio sina i kćer. Dok je najamnica, Anera međutim obavlja svoj posao kao da je na vlastitom polju, daje sve od sebe, čini se kao da posluje za kraljevstvo nebesko.

»Išla je, da zaradi, ali kad je radila, nije radila za cvanciku. Radila je za vječnost kao poslenik Božji u vječnom, neprekidnom djelu stvaranja, obnavljanja, oplođivanja, rađanja. Ostali težaci većinom nijesu bili osobito oduševljeni, kad su bili s njom na istoj njivi, jer nije nikada mogla osjetiti u svojoj duši značenja njihovih riječi, kad bi joj šapnuli: 'Štedi se, Anera. Nije ti ćaćino, ne budi bluna.' ${ }^{87}$

Negativna uloga žrtve sigurno bi bila šutnja o zločinu koji je nad njom pokušao počiniti silovatelj Blažić. Možda nije posve točno reći da Anera traži ulogu žrtve, no tako na kraju ispada. Time ovaj lik odstupa od načela koje zadaje Lynette Porter. Pri toj šutnji o zločinu valja opet istaknuti još nešto, jer pojedinost držim bitnom. Razlikovao bih naime književnu osobu od književnoga lika. Anera kao osoba zaista ima nedostatak u tome što ne javlja nikomu o zločinu koji je nad njom počinjen, naime o pokušaju silovanja. Rečeno je nedostatak nje kao osobe, ali nije nedostatak književnoga lika. Ona je dosljedna do kraja u odanosti načelu sućuti i davanja te konačno je vjerna žanrovskomu uzoru molitelja.

\subsection{RAZVIJA SE: IAKO JE IMALA PRIKRIVENE JUNAČKE OSOBINE, POKAZUJE IH KAD VALJA ZAŠTITITI DOBRO I ISPRAVITI NEPRAVDU}

U samom Blažićevu napadu ona se dobro obranila kad je posegnula za napadačevom britvom. Anera međutim nakon nasilja nad sobom ostaje zarobljena svojom naravi i vjerojatno običajima okoline u kojoj živi. Na ovom bismo mjestu rekli kako Anera pokazuje razvojnost kad shvaća da mora naći drugoga supruga jer vidi da se sama ne će obraniti od Blažića i zaštiti svoje sinove. Iako ne voli Lukana ni izbliza kako je voljela Mićana i to mu jasno kaže, ona mu nudi brak. Prvotna misao o ljubavi i samo ljubavi, koju je zastupala u navedenoj konverzaciji sa sestrama, sada

${ }^{87}$ Isto, 99., II. 
se promijenila. Anera vidi koja je prednost bogata imanja i snažne muške ruke, ali ujedno štuje poštenje i sposobnost drugoga supruga kojemu pomaže očuvati njegovo ognjište.

\subsection{ZASTUPA VRIJEDNOSTI DOMA I OBITELJI ${ }^{88}$}

Anera čuva svoju djecu i misli na njihove interese. Stoga i traži da Blažić na nju prenese dio svoje zemlje. Nakon toga Lukan čini još jedan mudar potez, kojim očito udara antagonista Blažića, jer ispisuje iz nasilnikove zadruge upravo njegove unuke, Anerinu djecu iz prvoga braka s Blažićevim sinom Mićanom. Djeca ulaze u Lukanovu zadrugu, iako su i otprije živjeli s majkom.

Anera misli i na tuđe ognjište, pa ćemo podsjetiti da je to razlog zašto ne odaje Blažića. Kako bi spasila Lukanovo ognjište, ona se za njega i udaje - iako je to samo dio razloga, a drugi je u tome što traži sigurnost za sebe i svoju djecu. Lukanova joj je obitelj toliko važna da izgovara i već citiranu misao po kojoj bi rodila Lukanu djecu i kraj živa Mićana.

Prije navedena obilježja grade Aneru kao veliku književnu osobu i obogaćuju žanrovsko tkivo romana, ali je presudna činjenica da njezine karakteristike ujedno tvore ženu koja je jasan i moćan dio životne stvarnosti.

\section{Anera na razini Budakova opusa}

\subsection{SuprotNi LIKovi}

U romanu Ognjište nema ženskoga lika koji bi po etici i uvjerenjima bio suprotan Aneri, a mogao bi joj parirati po svojoj snazi, ulozi u pripovijesti i izgledu. Tu je ulogu odigrao muški lik Blažić. Stara je baba Anđuša krezuba i krmeljiva te nosi blatnu i poderanu odjeću, a nema osobitu ulogu u djelu - iako je na Blažićevoj strani. Dok je još u Lukanovoj kući kao najmenica, Aneri se suprotstavlja Makićeva supruga Jela. Ona želi da Lukan utrne svoje ognjište i opet uđe u zadrugu svojega pokojnoga brata, čime bi postala planinka u znatno većem gospodarstvu. Planovi će joj se izjaloviti kad se Lukan i Anera uzmu i dobiju djecu.

Pozitivne ženske osobe, kakve su prva Lukanova supruga Anica i vjerojatna treća supruga Manda, zapravo su vrlo slične Aneri i djeluju kao njezine oslabljene inačice. Sve su one prije svega plastično predstavljene, odane obitelji, pobožne, strpljive i određene ulogom majke i supruge - ali svaka ima svoja obilježja, posebne su u svojim usudima i jasno su ocrtane. Isto se može reći za Aničinu kćer Matiju te Blažićevu kćer Barušu. Srodnih ženskih likova ima, naravno, mnogo na razini Budakova

${ }^{88}$ Usp. L. PORTER, Unsung Heroes of The Lord of the Rings, 20. 
opusa, a sada možemo tek spomenuti Iku iz Kresine, Vranjicu Kacana Brkljačića iz Hajduka, Seku iz Gospodina Tome i Kaju Viduke Peršića iz Bazala.

Pravu žensku suprotnost Aneri valja tražiti na razini Budakova opusa, a najbliža je toj odrednici Anica Kacana Brkljačića iz romana Hajduk. Svojega supruga Nikolu Josinova Kresojića zadobila je prijevarom sestre Vranjice, a pri pojavi nevolja napušta muža i djecu te ljubuje s Pavlinom Japunčićevim. Suprotnosti između Anere i Anice kreću se po oprjekama ljubav - seksualnost; lukavstvo - inteligencija; muka za drugoga - užitak u svojem tijelu; pobožnost - konformizam. $^{89}$

\subsection{Oproštaj s Anerom}

Anerina je važnost na razini opusa istaknuta pojavom u posljednjem napisanom Budakovu djelu. Pisac je 28. ožujka 1945. godine dovršio roman Bazalo. Iako on sâm nije znao da mu je to posljednja knjiga, koban je kraj mogao slutiti, što je vidljivo u nizu motiva smrti rasutih po završnom ciklusu romana o obitelji Kresojića. Kako je rečeno, Vojni sud Druge armije, vojske komunističke države Jugoslavije, osudio je Budaka na smrt 6. lipnja 1945. godine i on je obješen dan nakon toga..$^{90} \mathrm{U}$ romanu Bazalo glavni lik Ivan, mistik i pučki liječnik, sreće u Babića gaju u Svetom Roku upravo Aneru Markićevu. Kad ga Anera pita kamo ide, kazat će joj da polazi za njezinim Mićanom, što znači u smrt. Riječi su znakovite za samoga autora, kojega su također znali zvati Mićom. ${ }^{91}$ Bazalo će još reći Aneri, kojoj su oči bile isplakane od suza, da se moli za njega. Onda će joj pružiti ruku, što inače nije činio. Slijede posljednje riječi upućene nekomu ljudskomu biću: »Blago tebi, Ane, u mukama tvojim. Blagoslovljena si duša. $\ll{ }^{92}$ Tako je i Budaka u smrt ispratila Anera Babić Markićeva - kojoj je spomenik i danas pred crkvom u Svetom Roku.

\section{Zaključak}

Anera je pomno elaboriran, ali prije svega živo realističan i stoga jasno vidljiv lik. Zadovoljava sve uvjete koje tragični žanr postavlja pred moliteljicu i većinu uvjeta za vodeću junakinju. Anera je žena od krvi i mesa, no s dubokom sućuti i jasnim kršćanskim duhom kakvoga imaju samo najveći likovi zapadne književnosti. Njezine su prave književne sestre Ofelija, Julija, Cordelija, Margarete i gospođa de Bauséant

\footnotetext{
${ }^{89}$ Za karakterizacije Anice Kacana Brkljačića usp. M. BUDAK, Hajduk, 14., 17., 42., 45., 159., 162., 164., 167., 318., 353., 419.

${ }^{90}$ Usp. T. JONJIĆ, S. MATKOVIĆ, Iz korespondencije dr. Mile Budaka (1907. - 1944.), 181-185.; J. JAREB, Prilog životopisu dra Mile Budaka, u: V. NIKOLIĆ (ur.), Mile Budak Pjesnik i mučenik Hrvatske, 1990., 92-93.

${ }^{91}$ Usp. T. JONJIĆ, S. MATKOVIĆ, Iz korespondencije dr. Mile Budaka (1907. - 1944.), 499.

${ }^{92}$ M. BUDAK, Bazalo, 422.
} 
- u tom izabranom društvu Anera zauzima posebno mjesto stoga što je po nizu obilježja bliska protagonistima. Ona je velika u svojoj poniznosti, uzorna u svojoj krvavoj borbi, nepovratno svoja u etičkim stavovima i konačno je bolno poučna u svojim pogrješkama. Stoga je Anera bila i ostala vodeći ženski lik hrvatske književnosti. 


\section{BUDAK'S ANERA AS A SUPPLIANT AND A HERO}

\section{Dean SLAVIĆ*}

Summary: As a manifestly hybrid genre, the novel can contain also elements of tragedy. In tragedies and tragic narratives, a suppliant regularly fulfils four characteristics: a) she is a female or a person in a subordinate social position; $b$ ) she is threatened by violence and often death; $c$ ) she cannot speak or communicate her problems; and d) she is neither a protagonist nor an antagonist. Anera from Mile Budak's Ognjište (The Hearth) presents all of the mentioned characteristics, with only a partial deviation from the fourth one. She is given a great amount of space in the novel and in intelligence is very close to the hero Lukan. Anera also fulfils, to a good degree, the conditions placed before a hero by Lynette Porter (an expert in English, rhetoric and composition), lacking, however, elements of victory over evil, which is achieved by Lukan. From Anera's position Budak's novel could be described as a tragedy of revenge, only that her characteristics do not determine the novel's genre-defining whole.

Keywords: Mile Budak, The Hearth, Anera, tragedy, novel, suppliant, main protagonist.

\footnotetext{
* Full Prof. Dean Slavić, Ph. D., Faculty of Humanities and Social Sciences, University of Zagreb,
} Ivana Lučića 3, 10000 Zagreb, Croatia, dean.slavic@gmail.com 